\title{
The Methodology of Creating "Terminology" in Rhetoric and Criticism Terms Dictionaries
}

\author{
Dr. Abbas Abdul-Halim Abbas \\ Arab Open University, \\ Amman, Jordan
}

\author{
Dr. Ayman Yasin \\ Princess Sumayya University for Technology, \\ Amman, Jordan
}

\begin{abstract}
This paper addresses the classification of scholars' interests in the rhetoric and criticism terms when creating dictionaries. It further gives examples of the most prominent works in this field. After that, the research studies one of these works. Thus, the paper goes gradually from the general to the specific to explain the main argument and prove it by concrete evidence. Through the paper, the researcher uncovers the dominant approach in this field. The paper starts with the historic methodology used by some scholars, and then it moves to the descriptive methodology used by others. The researcher also reviews the flaws of using the alphabetical method used in both methodologies. The research concludes that lexicologists and researchers have to reconsider the way they build dictionaries and set terms. It also suggests that a term dictionary is a not a list of terms but a system.
\end{abstract}

Keywords: literary criticism, dictionary, terms, terminology, rhetoric

\section{Introduction}

The interest in a "term" of a science field is the interest in the essence of that field and its primary concept because the term is a descriptor of its origin, a conveyor of this science, and a basis for the future of that science. Because of this realization, an active movement in specialized dictionaries has been formed and undertaken by institutions and language academies. Individuals in a various Arab countries were concerned about it. This "dictionary" activity would not have formed if there were no real sense of the necessity of controlling, tabulating, and organizing the terms of any science that ensures correct understanding and proper curriculum for concerned people. Then, we started to hear a variety of titles of "terms" dictionaries such as: Psychology Terms Dictionary, Military Terms Dictionary, Administrative Terms Dictionary, inter alia. It is no doubt that the need for precision and organization in criticism terms field is tougher and deeper, particularly in knowledge fields that its inputs are no longer limited to what a single language produces. Rather, the presence of translators and newcomers from other languages become essential in such fields including primarily Literary Criticism.

\section{An Attempt for Classification}

The care of linguists, terminologists, and interested researchers has two folds: The first was theoretical. It included the studies that were specialized in "the term" and lexicography, especially those which addressed special lexicological issues whether in part or in whole. It seemed to me that those could be classified into four fields:

Dr. Abbas Abdul-Halim Abbas, Ph.D., Arabic Department, Arab Open University.

Dr. Ayman Yasin, Ph.D., Coordination Unit for Service Courses, Princess Sumayya University for Technology. 
(1) Conferences, symposiums, and special volumes in literary periodicals that were concerned with criticism terms and their specialized lexicography;

(2) Books and complete thesis that discussed criticism terms and related issues;

(3) Research papers and studies published in refereed periodicals, and chapters in books that discussed an aspect or more of "literary terms";

(4) Public articles that discuss "the term" published in public cultural and literal periodicals.

Perhaps the order that was mentioned before reflects the gradual importance of these efforts. It shows that the conferences and symposiums on local, Arabian, or international levels discussing the terms of criticism and their lexicography come on the top priorities since they reflect the worry that the conferees and the attendees have about the problem of criticism terms and their lexical meaning. Despite the hard job of collecting all relevant papers presented in these conferences and special issues, the researcher tried his best to get as many of these papers as possible in order to have a representative sample that could reflect the image, vision, and concern of the people involved in this field. To have a closer look of these perceptions, I will mention some of the most prominent works in this filed:

(1) International symposium in Al-derasah al-mustalahiyah wal-'ouloum al-islamiyyah (The "Term" Study and Islamic Sciences), Seedi Mohammad Bin Abdullah University, Fas, Jazaan, 1993 AD;

(2) A symposium about Qadayah al-mustalah Fi al-aadaab wal-'ouloum al-insaniyyah (Term Issues in Literature and Human Sciences), Mawla Ismael University, Faculty of Literature and Human Sciences, Meknas, $2000 \mathrm{AD}$;

(3) A symposium about Al-mustalah al-naqdi wa 'alaqatuhu bi-mukhtalaf al-'ouloum (The Criticism Term and Its Relation With Other Sciences), in a special issue of the journal of Faculty of Literature and Human Sciences in Fas, No. 24, 1988 AD;

(4) A symposium about Al-mustalah: qadaayaah waishkaaliyyaatuh (The Term, Its Issues and Problems), within a special issue for the journal of Landmarks in Literary Criticism, Literary Club, Jeddah, issue 8, Volume 2, $1993 \mathrm{AD}$;

(5) File of Al-mustalah al-naqdi (The Critical Term), in a special issue in the Fusoul journal, issues 3 and 4, Volume 7, April-September 1987 AD.

Perhaps the hermeneutical read for the titles of these texts and research papers presented in these files and symposiums tells us how humble is the Arabic work of "the term" in the "literary criticism" field. Otherwise, how could we explain holding a dedicated conference about "the 'term' issues of literature and human sciences" ${ }^{1}$ in which the participants were concerned about establishing an initial theory that seeks to define the concept of the term and the nature of term structure and suchlike? The prevailing feeling here is that the study of Arabic term in literary criticism field is still crawling, as is the case in lexicography field. ${ }^{2}$

So we are not able to endorse the general issues of the term. We have not either gone beyond the primary fundamentals yet to negotiate more specific and deeper details in the philosophy of lexical projects of criticism terms.

\footnotetext{
1 This was the title of a symposium that was held in Mawla Ismail University in Meknas, 9-11 March, 2000.

2 Some of the conference proceedings were: "The Structure of the Term: Theoretical Nature and Applied Patterns" by Dr Jawad Sama'neh, pp. 41-66; "Issues in Structuring “The Term”" by Dr Amina Afnan, pp. 67-90; "The Concept of 'the Term"” by Dr. Idrees Al-Tarrah, pp. 91-95.
} 


\section{An Analysis Sample}

Let's take another example for one of the research files that were published in one of the criticism periodicals on the term in the field of literary criticism. A number of major critics and Arab researchers participated in this file like Abdul Al-Salam Al-Musdi, Ezz Al-deen Ismail, Hamadi Sammoud, Abdul Al-Wahid Lu'lu'ah, Mohammed Abdul-Muttalib among others. Let's look wholly at the features of the nature of studying criticism terms and the technical visions that come up. Generally speaking, they are features that are almost enclosed between general term drafting mechanism, and other insights that study the bases of the term. $^{3}$ This indicates that those features were more concerned with general term issues that express individual attempts to establish specialized literature in criticism terms. It also indicates the absence of institutional literature in the development of contemporary Arabic literary criticism. At the same time, we have an abundance of critical accomplishments in the fields of curricula and critical theories and their procedural applications on various literary texts. As a result, the researchers who made those attempts found themselves facing serious challenges regarding the lack of a well-established term to count on and refer to in literary criticism. Therefore, the analysis of the ideas contained in these pieces of research points out two important issues:

First: the individual flavor for establishing criticism terms on the theoretical and practical levels. The efforts that discuss the problem of the term and its coinage are far away from the institutional work that revolves around the role of specialized research institutions in the field of terminology, not to mention that such institutions do not even exist. Although the linguistic centers address the term as part of their activities, they are dedicated to it entirely. As a matter of fact, the duties of the "terminology" work shall be handed to,

Scientific and technical organizations, higher education institutions and universities, professional organizations, specification institutions, managerial and governmental bodies, information and knowledge institutions, and under certain exceptional cases, individuals who mostly pave the way for certain committees in scientific, technical or professional organizations to define or develop certain terms. (Flipper, 1988, p. 206)

Researcher may notice that the efforts presented by Abdullah Al-Ghathami or Abdul-Salam Al-Masadi, Ezz Al-Deen Esmail, and Tawfiq Al-Zaydi, even Abdul-Qader Al-Fasi Al-Fahri are considered as individual efforts which are not based on academic and scientific institutions or organizations.

Second: neglecting Arab term heritage and ignoring it, as if criticism term started out of scratch. For example, a special issue of Landmarks in Literary Criticism Journal was dedicated to the term. It included a symposium specialized in "The Term: Its Issues and Problems" as well as nine specialized research papers. However, it was almost devoid of views in the fundamentals of criticism terms used by ancient critics and Arab researcher. Perhaps Mohammad Abdul-Muttalib's research is the only one that came nearly close to that although it was oriented and confined to specific terms. In fact, the beginning of his research unraveled his desire to thoroughly study the terms of ancient Arabs grammarians and critics. Abdul-Muttalib (1993) explains that,

Looking into these terms indicates that they originated from three sources. Some belong to the innovator (writer), some to the receiver (reader), and most to the text itself. In general, we can notice some sort of overlapping suggesting that

\footnotetext{
${ }^{3}$ See "Remarks in Literary Criticism", a special issue about "The term and its Problems", issue 8, Vol. 2, 1993. See also "The Criticism Terms and Mechanisms for Coinage" by Abdul-Salam Al-Masadi, pp. 53-108; "The Crisis of the Criticism Terms" by Abdul-Wahid Lu'lu'ah, pp. 161-168.
} 
the term may relate to two sources, or even to three. This means that the old method of teaching was familiar with the connection process between the three sources and the triple pillars. (p. 198)

Accordingly, Abdul-Muttalib formed his terms in this tri-directional approach whose theoretical philosophy can be invested in uncovering the process of rhetorical and critical term in our heritage and culture. The approach is considered as a scientific achievement in establishing an Arab effort that develops the theory of the term; "a theory that involves the rhetorical and critical terms which have signs about the procession of the literal and critical culture and the language of the nation in which they emerge. Terms are the fruit of the literary, linguistic and creative procession, and they are connected to the culture" (Yaghi, 2003, p. 32). Terms have shed light on our modern culture despite all of the modern features we live with. This is best explained by specialists who describe the interrelations between modern and old rhetorical, critical, and linguistic terms such as intertextuality and its relation with plagiarism, stylistic deviation and its relation with negligence, necessity, and irregularity, ambiguity and its relation with vagueness and complexity, and other issues that show that the old term is considered as a prerequisite and the origin for the modern term.

However, these views represent the beginning of real efforts that were exerted to establish an Arab critical term project since this kind of project "requires some sort of knowledge foundation that depends on consecutive stages which, in total, lead to total to what we call literary criticism science" (Al-Masadi, 1994, p. 9). This, in turn, will qualify such a project to be present among regional and international projects that are interested in the literary criticism term. In fact, all previous attempts did not pay any attention to the literary criticism field as one of the human knowledge fields that is supposed to have its special terms achievements and that is capable of addressing its own terms according to the general terminology theory or its sub-theories. Such theories were almost completely directed towards scientific fields such as medicine and engineering.

To account for such negligence in the literary criticism field, Ahmad Matloub states that,

In Arabic academies, there was little attention given to the terms of linguistics, criticism and rhetoric because these academies, since their beginnings, were more concerned with following up the scientific progress in the west and setting up the scientific terms in different fields of knowledge. Perhaps the attention of these academics to civilization terminology was wider because of its relevance to people's lives. Thus, the negligence of criticism terms may be related to:

(1) There are a lot of terms about Arabic criticism, thus writers and researchers can use the old ones;

(2) Literary criticism does not have as much effect on language and its trends as modern sciences' terms. Therefore, there was no objection to the foreign or Arabicized terms as long as they are few;

(3) Writers and authors have begun creating criticism terms for a long time. They also agreed on most of them. So, these terms were commonly used;

(4) Criticism is not related to scientific advancement that the world witnesses. Contemporary life imposes scientific interests. This trend has led to neglecting humanities most of the time. (Matloub, 2002, pp. 13-14)

\section{Comment and Critique}

It seems that these explanations are valid to some extent. However, they are not based on scientific evidence or empirical research. First, how can we judge that literary criticism does not affect language and its trends as much as modern sciences and their trends? How can one claim that old terms spare us the need to pursue new ones? Aren't creative contexts and constant changes in the literature theory able to create a critical debate that is capable of creating new terms in a language? Was the agreement on criticism terms since an early age the standard and anything else exceptional or irregular? 
In addition to all these inquiries, the interest that was referred to in the scientific and technical fields and their terms was not as needed. As a piece of evidence, we are living in the 21th century. However, we are still suffering from,

Double term gap, a gap in the term generating tools represented in our inability to pursue the accelerating demand for the term, since thousands of terms are added every day. There is also a gap in finding unified terms among Arab countries. (Ali \& Hijazi, 2005, p. 351)

Naturally, this increases the difficulty of the mission that scholars of criticism terms undertake since they encounter more challenges. On the top of these challenges comes the connection of the term to scientific research since it is an integral part of it. This, in fact, takes us to rethink about the special problems that Al-Masadi dubbed "quality channels". These channels are associated with the knowledge field that the term belongs to since there is no chance that the search in the term breaks apart from the search in the same field. Therefore, the field's problems certainly affect its terminology. Al-Masadi (1994) pinpoints that,

Despite the common factors between all knowledge fields that control the subject of generating terms which refer to the precise concepts inside a certain language, every single art or field of knowledge has its peculiarities that unsurprisingly provide the linguistic traditions with a lot of marking terms that differentiate a field from the others. (p. 10)

\section{Controllable Approach}

Regarding the manuscripts that were entirely dedicated for criticism terms and their issues - though few - they represent what could be called a structure for establishing lexicological criticism terms. It is hoped that such a structure transfers the criticism terms from chaos to order and institutionalization either through works that represent opinions and theoretical approaches in the context of terminological research, or through works in lexicology and its various applications. This may include the study of criticism term of a particular author, or in a particular environment. The university institution, no doubt, has an important role in conducting such pieces of research such as scientific theses in graduate studies.

It is obvious that the individual terminological studies for criticism terms, which appeared in academic context about figures of our rhetorical and critical heritage, such as "Al-Jaheth", "Ibn Al-Mo'taz", "Ibn Qutaibah”, “Ibn Tabaatba”, “Abdul-Qaher Al-Jurjani”, “Al-Qurtajni”, “Al-Sajlamasi”, and others, was the right start. We followed this approach indeed, because it is characterized with personal diligence and instinctive tendencies. It is evident that the end of those scholars' work has led to opening the door for studies and research papers which we need most. Perhaps, academics at some of the Arab universities are the first who broke through this field since they advise the graduate students to write in the criticism terms adopted by a critic or a group of critics and linguists. Thus, a library of criticism terms has started to appear. Some of the well-known works in this filed are:

(1) Criticism and Aesthetic Concepts in the Literature of "Al-Jahez", Michaele Assi, 1974;

(2) Criticism Terms and Rhetorical in Al-Jahez's Book "Al-Bayan wa Al-Tabyeen" (clarification and explanation) by Al-Shahid Al-Boushikhi, 1977;

(3) Criticism Terms in "Naqd Al-shaer" (poetry criticism) book by Idrees Al-Naqouri, 1982;

(4) Rhetoric Term in "M'ahed Al-Tansees Ala Shawahed Al-Talkhees" (quotation norms on summarization) by Abdul-Rahman Al-Abbasi $(963 \mathrm{H})$, Mohammed Khalil Al-khalayleh, 2006.

There were also other academic theses that were not published such as: 
(1) Rhetoric terms in "Al Sina'atain" (The two industries (writing prose and poetry)) book, Abdul Kareem Bakheet, Yarmook University, 1988;

(2) Criticism Terms of Hazem Al Qirtajni: A Dictionary, Interpretation, Resources and Problems, Abbas Abdul-Haleem Abbas, Al-Yarmook University, 1991;

(3) Rhetorical Terms in Ibn Rasheeq Al-Qerawani's "Al-Omda" (The Argument in Syntactic), by Mohammad Al-Khalayleh, The University of Jordan, 1993;

(4) Criticism and Rhetoric Terms of "Abi Ali Al Hatimi”, by Badie Al-Azzaam, Mu’ta University, 1994.

\section{Two Methodologies}

When speaking about the methodology in studying criticism terms, it appears that the Historical and Descriptive methodologies take over in this kind of studies. In fact, Al-Boushikhi restricts the methodologies that researchers of the term used only to those two approaches.

According to Al-Boushikhi (1988, p. 24), the Historical Approach was invented by the Iraqi school represented by three books: Rhetorical Terms, The Lexicology of Rhetoric Terms and Its Development, and Criticism Terms: Roots and Development up to the End of the Seventh Century AH. These books appeared to trace the developments of some term in rhetoric and criticism.

The main objection to this approach lies in the inability of some individuals to trace the emergence of a term and its development over time.

There is no doubt that this goal is very correct and authentic. Who does not like to have the etymology of terms of rhetoric and criticism, and other fields? Who does not dream about the etymological dictionary of criticism terms and terms of other fields? However, the main question is who can really accomplish that? Is it scientifically and methodologically acceptable to start such a project? (Al-Boushikhi, 1988, p. 24)

From a methodological point of view, monitoring the developments of any term requires tracking the stages of the term in every single step of its life.

Scientifically, those studies and that monitoring of the stages will not have the scientific results unless it meets the conditions of scientific method. On the top of that comes the full understanding of the subject. The historical methodology of studying terms is very important if it meets its conditions and requirements. Otherwise, its results are scientifically and methodologically invalid (ibid., p. 24). Although the previous argument is largely true, we have been looking forward to having an etymological dictionary for terms of criticism as much as we longed for an etymological dictionary for Arabic. However, there is an obvious difference between an etymology of the language and an etymology of the criticism terms. It is likely that criticism terms would be easier since they are spatially and temporally restricted. In addition, using a statistical approach would be easier after obtaining an etymological one.

The second approach which Al-Boushikhi referred to is the descriptive one that is represented by-more or less-three books: Qudamah bin Ja'far's naqd al shi'er (Poetry Criticism) which contained vocabulary of rhetoric and literally criticism, criticism and aesthetic concepts in the literature of "Al-Jaheth", rhetorical and criticism terms in Al-Jaheth's Al-Bayan wa Al-Tabyeen (Rhetoric and Explanation).

The scientific need which these books came to fill is the definition of semantic terms for criticism and rhetoric terms in a particular book, or of a particular writer. It would be beneficial if this complies with the following conditions:

(1) Counting all texts in which terms were included in a book or textbooks occurred; 
(2) Studying terms in lexical dictionaries and term dictionaries to pave the way to term philology appreciation;

(3) Studying terms of the materials in the counted texts in order to classify each material depending on how terms are used. The results are classified based on the meanings of each term if there is more than one;

(4) Presenting the results in the form of a terminological study that takes into consideration the mentioning of the characteristics of the term such as the features and adjectives...as well as mentioning the correlations between the term and other terms, and showing similarities.

Al-Boushikhi believes that "The adoption of this descriptive approach at this level of studying terms is some sort of rationality. Nevertheless, during application it needs a considerable level of control and integrity so that its results would be reliable" (ibid., pp. 25-26) because the description deals with the reality of the existent terms on one hand, and in line with the synchronic approach in studying the linguistic phenomenon on the other hand. Such approach examines the language internally depending on the inputs of the philological approach. Al-Boushikhi did not mention the intersections and overlaps of this approach whether these overlaps were with the historical or descriptive methodology since the philological approach looks into in "the vocabulary problems in terms of their meanings, originality, features, synonymous, coinage and non-morphological derivations” (Ya'coub \& 'Assi, 1987, p. 953).

This way helps a lot in the study of the terms which embody specific intellectual articles in a certain scientific and technical era. For example, we find Idrees Al Naqouri's Criticism Terms Used in Poetry Critique, which Al-Boushikhi classified as belonging to the descriptive approach, addresses the "prosody" term merely descriptively. However, this term gets into many problems that cannot be ignored such as mixing between the linguistic meaning and the terminological meaning between that critics and narrators used. For instance, Al-Asma'e used the word "prosody" in its linguistic meaning, while Ibn Al-Mo'taz used it in its terminological meaning. Unfortunately, this difference did not attract Al-Naqouri's attention who was especially concerned with terminology. In addition, Al-Naqouri does not miss a chance in tracing the occurrence of the term in all texts of those who came before him. Accordingly, Al-Naqouri's is no doubt is a piece of historic research.

\section{Necessity for Terminology}

If this were the concern of applied publications which addressed the term from a lexicological standpoint, then what concerns those who are interested in the theoretical aspects? The library's indices point out to a limited number of these works on one side, and to their contemporariness on the other side. This, in turn, leads us to say that application in this field preceded the theory. Although terminology is defined as "a field study to dub the concepts that belong to specialized fields in human activity of social activity in terms of their social functions" (ibid.). On the one hand, terminology includes formalizing a theory and methodology to study groups of terms and their development, and on the other hand, it includes gathering terminological information and sorting them out. It also entails putting this information into criteria when necessary whether that information was monolingual or multilingual.

If we look at the purposes, functions, and research methods of this science, we can determine its nature and identity. The major three goals of terminology—as clarified in its definition —are:

(1) Formulating the principles that govern creating new terms;

(2) Unifying the existent terms and setting criteria for them;

(3) Documenting the terms and publishing them in a specialized dictionary (Al-Qasimi, 1988, p. 85). 
It can be said that these books which addressed the theory of the term in "literary criticism" are limited. In addition, they are more concerned with the term outside the lexicological framework to a great extent. Here are some of the most prominent books:

(1) Al-Shahid Al-Boushikhi (1993), Arabic Criticism Terms for Islamic and Pre-Islamic Poets, Issues and Models;

(2) Abdul-Salam Al-Masadi (1994), Criticism Terms. Tunisia: Abdul Karim bin Abdullah Publishers;

(3) Ahmad Matloub (2002), About criticism terms. Baghdad: Al-Majma' al-elmi’ Scientific Academy;

(4) Ezzat Ali Jad (2002), Theory of the Criticism Term. Cairo: Al-hay'a al-masrya al-ammah li-l-kitab (The Egyptian General Authority for Books).

The issues raised by the authors of these works express the desire to establish a dictionary of terms according to scientific methodologies. Perhaps the awareness of lexical dimensions of terminological issues was confined to two: Al Boushikhi classified the book Arabian Criticism Terms of Pre-Islamic and Islamic Poets: Issues and Models into two volumes. He dedicated the first to studying the problem of methodology observed in the study of the Old Arabian Criticism, and issues related to this general term such as its nature, origin, criteria for creating it and its development mechanism. The second volume was a dictionary of the criticism terms used by the pre-Islamic and Islamic poets. This was done on the basis of historic and descriptive methodology whose features and importance were presented and explained by the author himself. This is an essential step which became a landmark in the terminological labor draft that of literary criticism. This draft, however, did not often give attention to the methodology. In best cases, when it paid attention to the methodology, that happened either covertly or lately. Unfortunately, this affected Arab studies in different knowledge fields. Abdul Aziz (2000) comments that,

Arab scientists used to follow a methodology based on controlled scientific bases. However, it took a long time to settle and develop just as other sciences and their terms. The methodology used in all fields of science was observed to varying degrees, and scientists used it consciously at a certain point, but they rarely declare it. Nevertheless, in the era of science prosperity, especially when logic was studied in-depth, they paid much attention to the methodology of creating terms, declared and detailed it. (p. 10)

No doubt that the widespread of knowledge and cultural openness that the literary criticism and its topics and terms have witnessed drove researchers to uncover the methodologies they used to deal with the terms and study them inside and outside the dictionary. This was, in fact, the scientific attempt that Al-Boushikhi has accomplished in this matter.

Ahmad Matloub is one of the scientists of the term who is concerned about building term dictionaries. His (2002) book Fi Al-MuSTalah Al-naqdi (About Criticism Terms) was a scientific of writing term dictionaries. In it, he followed traditional methods most of the time. In addition, he tackled a wide range-spatially and temporally — for a number of criticism and rhetorical terms issues that appeared in specialized papers. To some extent, Matloub was trying to approach new terminological issues. He addressed some proposals of the pending translation problems that are related to the term, and some linguistic overlaps in the same frame. ${ }^{4}$

If Al-Boushikhi has put the terminological research on the scientific track through realizing which methodology to follow when teaching the term, Ahmad Matloub's achievement in About Criticism Terms came in the same context of awareness and importance. First, he raised the criticism terms problem and addressed

${ }^{4}$ Matloub collected most of these articles in a book Research Papers in the Term and published it in 2006. 
their aspects since this problem exists in every terminological venue in the different fields of science. Second, Matloub was also aware of the necessity to create a terminology dictionary which organizes literary criticism terms and represents a holistic reference for them. For instance, in a chapter titled "Towards a Dictionary of the New Criticism Terms", the student finds that what Matloub addressed in this chapter was not intended to go deep in the current terms of the literary criticism. Rather, he opted for describing old and new dictionaries. He, then, descriptively went over a number of the terms dictionaries that are used nowadays:

(1) Nasser Al-Nani (1955), The Term in Western Literature;

(2) Majdi Wahbeh (1974), Dictionary of Literary Terms;

(3) Hammadi Sammoud (1977), Dictionary of Modern Criticism Terms;

(4) Abdul Wahid Lu'lu'ah (1978), Encyclopedia of Criticism Terms;

(5) Jabour Abdul-Nour (1979), The Literary Dictionary;

(6) Majdi, Heba and Kamel Al-Mohandes (1979), The Dictionary of Arabian Terms in Language and Literature;

(7) Sa'eed Alloush (1984), The Dictionary of Contemporary Literary Terms.

Ahmed Matloub's analysis was characterized by brevity: It is an attempt to touch on some of the features of the methodology followed in each of these dictionaries accompanied by one or two examples for clarification.

Despite the importance of awareness raised by Matloub in making "the dictionaries of the criticism terms" a case of discussion, the analytical effort that he put in addressing "terms lexicology", was not deep enough to uncover the ultimate philosophy which the terminological study was based on according to the input of terminology. Nevertheless, we admit that Matloub is indeed a well-experienced scholar in the term lexicological field. He is the author of two well-known dictionaries: The Dictionary of Rhetoric Terms and Their Evolution (3 volumes) and The Dictionary of Old Criticism (2 volumes).

Matloub's methodology in "Towards a Contemporary Criticism Terms Dictionary" was characterized by: personal analysis, following the traditional methodology that lacks basics of Terminology, not following the procedures of the special and general theories for this science nor the contributions of contemporary linguistics, as well as the negligence of the essential resources for this type of studies. Nonetheless, Matloub tried hard to determine a set of tools, means, and work references that need to be followed to createareliable criticism terms dictionary. Before examining these means, let's just go over them (taken from Matloub, 2002, pp. 299-304).

(1) Tracking the Arabic criticism terms and discussing their significance and change over time whether they were terms for poetry or prose, old or new. These terms were created through different mechanisms such as derivation, metaphor, patterning, translation, creation, and even through Arabicization. As for blending, Arabic does not tend to use. The tracking process, of course, is done through surveying our Arabic literary, religious and philosophical heritage;

(2) Listing most important literature and criticism books and extract criticism terms that have been used in the 20th century in order to agree on the terms that accurately give the new meanings;

(3) Listing the most important literary terms and modern contemporary criticism books;

(4) Listing the most important philosophical, psychological, sociological and arts books and extract terms that are related to or can be a basis for literally criticism;

(5) Listing the most important linguistic books;

(6) Listing the most important translated literature, criticism, and linguistic books; 
(7) Taking a look at some foreign literature and criticism encyclopedias in their original languages;

(8) Utilizing some foreign language dictionaries to determine the relationship between the linguistic and idiomatic meaning and the way of senses transference;

(9) Agreeing on the terms after studying them thoroughly and before widely spreading them. In addition, the experienced members of language councils need to ignore the obsolete terms that do not meet any need;

(10) Classifying terms according to their letters to ease finding them since this is the way followed in terms dictionaries;

(11) Defining the terms linguistically and idiomatically accompanied by showing the difference between schools and providing a foreign equivalent or more;

(12) Revising the terms by a dedicated scientific committee and continuously adding new terms and modifying old ones when needed.

\section{Conclusion and Prospective Research}

All these steps are needed when writing terms dictionary not only for literary criticism, but also for any field of study. Nevertheless, most of these steps are, more or less, general information and common instructions that look like final recommendations for many symposiums and conferences, rather than suggesting a structure for linguistic basis and technical lexicography that serve as a step for writing dictionary of literary criticism terms. Such a structure enables the researcher to approach the efforts of specialists in the field of building the term who are concerned with the lexicological constraints in terms of phonology, morphology, syntax, and semantics. The researcher can, then, raise questions related to specialized knowledgeable and address the measures to give the terminological and lexicological meaning of that field's terms. This will enable us to find out his point of view with respect to "schools of the term" and which one we can depend on in our term work, whether theoretical or methodological? The search in any direction of the term theories "special or general" will push us forwards achieving such a dictionary. ${ }^{5}$

It is necessary to discuss possible ways to arrange the dictionary entries. Although Matloub mentioned the "alphabetical way" in the tenth step, he did not provide any justification for that except that it is "the method adopted in term dictionaries". In fact, this point lacks precision and desperately needs to be detailed.

Perhaps the efforts of the lexicologists in this issue were mainly concerned with arranging entries in a dictionary. ${ }^{6}$ The dictionary is not merely a list of words; rather it is a system of relations and senses. Therefore, if the dictionary's vocabulary were addressed in an ill-manner, we will break the cohesion and coherence between the elements of this system, and lose the deeply rooted relations in it. For instance, how would a reader understand the relationship between a line and a poem, a structure and a system, narrate and anecdote, and many others. This, in turn, indicates that "the adopted alphabetical order of the terms in general language dictionaries does not suit the language unusual glossaries; because the alphabetical order of the terms dissociates the intellectual and verbal structures of a thematic field" (Al-Qasimi, 1988, p. 84).

\footnotetext{
${ }^{5}$ Notably, there are three approaches that looked into the general and special theory of terminology: the objective approach, the philosophical approach, and the linguistic approach. The former assures the importance of the nature of concepts, their qualities, make-up, definitions, and the relations between them. Proponents of the philosophical approach stress the importance of classifying the concepts from a philosophical standpoint. The linguistic approach sees terms as part of the language utterances. Therefore, the study of terms require lexical, morphological, and phonological tools (see also Al-Qasimi, 1988, pp. 84-85).

${ }^{6}$ For more details, the reader is referred to Al-Qasimi (1983, pp. 20-51).
} 
No doubt, we are facing many other problems here. There is no chance to ignore them in any scientific study for a specialized dictionary for literary criticism terms. The most recent problems are related to the interference between "literary criticism" and other fields of knowledge, literature's relation with and other arts as well as the interrelated problems between the literature genres. Thus, how can we agree on a reliable standard for criticism terms that can be trusted for the adoption, description, and documentation of the term?

\section{References}

Abdul Aziz, M. (2000). The Arabs and the scientific term: History, resources and theory. Cairo: Dar Al-Hani.

Abdul Muttalib, M. (1993). The structure of rhetorical change. Alaamat Journal (Special Issue), 2(8), 198.

Afnan, A. (2000). Issues in building the term. In A symposium on issues in structuring "The Term" in literature and humanities. Meknas: Mawla Ismail University.

Al-Boushikhi, Al-Shahid. (1988). The methodology problem in studying old Arab criticism terms. Faculty of Arts Journal, 11(4), 24.

Ali, N., \& Hijazi, N. (2005). The digital gap: An Arab vision for the society of knowledge. Kuwait: 'aalam Al-ma'rifa.

Al-Masadi, A. S. (1993). The criticism terms and mechanisms for coinage' remarks in literary criticism. The Term: Issues and Problems (Special Issue), 2, 86.

Al-Masadi, A. S. (1994). The critical term. Tunisia: Abdul Karim bin Abdullah Institution.

Al-Naqouri, I. (1982). The critical term in poetry criticism. Al-Dar Al-Baydaa': Moroccan Bookshop Publishers.

Al-Qasimi, Ali. (1983). Order of dictionary entries. In Creating an Arab dictionary for non-native speakers. Tunisia: Arabicization Coordination Office.

Al-Qasimi, Ali. (1988). Terminology between logic and language. Al-Lisan Al-'Arabic Journal, 16(30), 65.

Al-Tarrah, I. (2000). The concept of the term. In A symposium on issues in structuring "The Term" in literature and humanities. Meknas: Mawla Ismail University.

Flipper. (1988). Terminology today. (M. H. Hulail, Trans.). Al-Lisan Al- 'Arabi Journal, 16(30), 65.

Lu'lu'ah, A. W. (1993). The crisis of the criticism terms, remarks in literary criticism. The Term: Issues and Problems (Special Issue), 2, 161-168.

Matloub, A. (2006). About criticism terms. Bagdad: Scientific Academy.

Matloub, A. (2006). Research papers in the term. Bagdad: Scientific Academy.

Sama'neh, J. (2000). The structure of the term: Theoretical nature and applied patterns. In A symposium on issues in structuring "The Term" in literature and humanities. Meknas: Mawla Ismail University.

Ya'coub, E., \& 'Assi, M. (1987). The detailed dictionary in language and literature (1st ed., Vol. 2). Beirut: Science for Millions Bookshop.

Yaghi, A. R. (2003). The critical term between heritage and plural awareness. Afkar Journal, 12(175), 32. 